\title{
Editorial: a new new deal
}

\author{
Anthony Allen Marcus · Kirk Dombrowski
}

(C) Springer Science+Business Media B.V. 2009

They say you can never step in the same stream twice, which makes it dangerous to argue from historical analogy. But they also say that those who don't know history are doomed to repeat it. So how is one to know which is the case? As we talk to our colleagues about the global crisis of accumulation-one that seems to be threatening to bring gigantic financial institutions crashing down on top of us and small businesses by the millions crashing down next to us-we are afraid that something of the latter is taking hold, and taking hold in way that threatens to take the political steam out of a crisis that, at least potentially, might invoke real change. These days it seems that knowing history has become way to relive the same dramas over and over again, without learning anything new. For those of us who must sell our labor to earn a living the temptation is to look for a familiar and comfortable historical narrative of crisis and redemption.

Before settling on a narrative we think it is worth asking the big question currently posed only by business channel talking heads: is this an 18 month recession spurred by the right-on-schedule-once-every-seven-years dip in the business cycle, or is it one of those great structural crises of accumulation that are thought to occur roughly every 60 years, like the "Great Depressions" of 18731896 and the 1930s? The answer matters; yet nearly every part of the political map seems to be assuming the latter and saying that what we need is greater and more up-to-date regulation to govern a financial system that has gotten out of control. It's an old story told by social democrats - mitigate the chaos of capitalism with order, decency, and more democratic input into where the social surplus goes. And while this remains a pretty convincing palliative for the terrifying rollercoaster ride that

\footnotetext{
A. A. Marcus $(\bowtie)$

University of Melbourne, Melbourne, Australia

e-mail: amarcus@unimelb.edu.au

K. Dombrowski

CUNY Graduate Center, New York, NY, USA

e-mail: kdombrowski@jjay.cuny.edu
} 
capitalism probably has in store for us, it begs the question of whether the correct historical analogy is being invoked.

The editors of Dialectical Anthropology are not ready to argue either for or against the seemingly rational response of shoring up collapsing financial institutions and trying to impose some order on the chaos. More serious discussion is still needed. However, all social scientists recognize that it is often the counterintuitive that is correct. When northerners are seeing more polar bears than ever before it may be a sign of a species disappearing in face of global warming, rather than a sign that it's time to raise the hunting quota, and earthquake-proofing often means allowing greater flexibility and planning for collapse.

So what are the specific narratives of crisis and redemption that are currently on offer? It seems that many see this as a moment to finally reverse the "neo-liberal globalization" that has been so thoroughly critiqued in social science. They want to go back to a time when capitalism was kinder, gentler and more local and corporations were held accountable by well intentioned, albeit clumsy and somewhat inefficient national bureaucrats. Indeed what we find most curious is the vast amounts of nostalgia out there for the economic regulation and Keynesian "pump priming" of the New Deal. We hear a tentative, but excited buzz about a new Works Progress Administration or a new Federal Housing Act, and the mantra of infrastructure, infrastructure, infrastructure, all as part of a new commitment to a more humanistic, less neoliberal, greener, better managed Keynesian economic policy. This we are told is part of what got "us" out of the 1930s depression, and who better to steward it than our ultra-calm, Ivy League educated President Obama who according to the buzz may or may not be somewhat like Roosevelt.

Oddly the urge for regulation, demand side economic adjustment, and a variety of vaguely New Deal like exercises seems to be coming from both big capital and the liberal left, and this is perhaps what makes us most uncomfortable. For the big capital interests who need emergency funds and guarantees of investment the reason is obvious, but for those who want to see a bit of Roosevelt in Obama and a bit of the New Deal in contemporary "neoliberal globalization," we wonder if this may reflect a peculiar nostalgia for good old days. These good old days seem to be defined by the familiar tropes of government regulation and concern for the unemployed, the disaffected, the fearful, and working families; countries used what they manufactured and they manufactured "real things"; and a social compact between government, labor and communities governed the rational flow of things and people. Our advice about such nostalgia is, as the Geena Davis character in Cronenberg's The Fly warned, "be afraid, be very afraid."

On the positive side we do notice that never before in our own memory has there been such widespread critical discussion of Roosevelt as a real policy-maker, rather than Roosevelt as a popular front hero. However, there is nothing more dangerous in arguing from historical analogy than even a hint of "good old days" nostalgia by those who weren't actually there. We wonder aloud whether we may no longer be in an era when the best approach to fighting the evils of "neo-liberal globalization" is Keynesianism (and we doubt it was actually ever a particularly good response to the depredations of capitalism). Today's Keynesian economic pump priming may be worse than yesterday's neo-liberalism, a thought that bears consideration when one 
notes that the World Bank has been arguing against simple faith in the market for almost 10 years now.

In this time, when we are all looking for a political narrative and some powerful ones are starting to emerge from the political parties, we thought it might be worth presenting a small balance sheet on Roosevelt and the New Deal and ask whether they were really an advance for the American working class or a set back at a time when significant alternatives were being posed in concrete form around the worldsomething largely missing in the current crisis. So, just to remind ourselves of what occurred, in order to think about what might have been possible, and what might now be possible, a few examples of looking at the glass as half empty follow:

- This was the period when Blue Cross and Blue Shield first emerged and government policy encouraged private insurers to take up health insurance, yielding the most expensive, most unwieldy, most unfair, and least effective national health system among the wealthy countries.

- The WPA drove down the price of labor and institutionalized lower social expectations for working people, for whom it became enough just to have a job. It discouraged female wage labour participation and was openly posed as a way of avoiding "dole" schemes, which might have made socio-economic life far less brutal during the last seven decades.

- The United States Housing Act hobbled public social housing initiatives that were being proposed at local and state levels, initiatives that often sought to bring together residents of different income levels. Instead, the USHA provided the basis for segregated, mortgage driven, banker managed social housing policies that have held back civil rights, racial and ethnic integration, fair and equitable educational funding, and a variety of other universal social citizenship projects. In fact, it may well be this very structure of expensive, privatized, individualistic, market driven social housing policy that was the catalyst to this latest crisis.

- The Social Security Act funded its program of senior support through payroll taxes, rather than a general fund, intentionally excluding roughly two thirds of the African Americans then in the work force and $50 \%$ of women workers. In this way, it provided a direct path to over a half century of economic inequality between the black and white sections of the American working class and created a variety of family forms that reduced the citizenship of women. Black family income is still, absurdly, roughly $50 \%$ of white family income in the US, and we would argue this is partly the result of this act.

- The Agricultural Adjustment Administration drove up the price of basic foods through subsidies to farmers, prompting the growth of an emerging corporate agricultural sector, while providing no relief to landless agricultural workers. It also provided the financial roots for the contemporary relationship between US agricultural subsidies, global agribusiness, and poverty in the agrarian third world. Whether and to what extent this will be continued and advanced by today's bio-fuels subsidy programs goes currently unasked.

Lest all of this be seen as cynical hindsight for otherwise well intentioned programs, it is also worth remembering that in 1938 Franklin Delano Roosevelt 
balanced the federal budget, causing the unemployment rate to spike to over $19 \%$, signaling at the very least a clear consciousness of whose interests were paramount. And finally, and perhaps not irrelevant today, is the fact that Roosevelt drove a policy of increasing conflict between Japanese and US imperial interests in the Pacific, which in the end proved the real solution to the $1930 \mathrm{~s}$ crisis of accumulation.

We realize that none of this is likely to be particularly new to our readers, and that we have failed to mention some of Roosevelt's most popular and successful acts, such as repealing the prohibition on alcohol (and thereby, together with his fireside chats and reassuring messages, making the depression a bit less depressing for ordinary folks). The point here is not only to trash FDR, an openly and avowedly pro-capitalist politician, but rather to remind ourselves about the trap of nostalgia, historical analogy, and jumping on a rational-seeming bandwagon of kinder, gentler state power. It is easy to forget that the New Deal was a hodge-podge of questionable pro-business legislation and small public relief, and that there is nothing particularly healthy, positive, or glorious about "producing real things" in real factories. It is tedious, health destroying, and probably best addressed through increases in fixed capital, in the form of computer design, robotic assembly, and rational economic planning.

So where does that leave the present? We fear for our limited pensions as much as the next wage laborer, and we, along with everyone else, keep fervently hoping that each move in this bailout process will work, because anybody, with the exception of a third period Stalinist, recognizes that a collapsing system is far different than one that is brought down and changed through purposive social action. However, in this case we question whether the cure maybe worse than the disease when gone into with heavy blinkers, and that is what we fear will happen when we follow the same logic out of this mess that got us into it-capitalist logic. Just consider that fact that if a bank that holds billions of dollars in mortgages goes under before the homeowners with the mortgages go under, there is a good chance that the complicated negotiations of bankruptcy will leave lots of families still in their houses, with mortgages that may be devalued to a market level far closer to what people actually earn, and that this is likely to happen in the "normal" course of bankruptcy negotiations. How, we wonder, is propping up the value of assets for which the owners already have no stake supposed to be worker friendly? The one thing that we can be sure of in this new government-banking collaboration is that those investors who own the biggest chunks of the biggest banks are being helped, and countless businesses and jobs will be pared away regardless of what happens in the banking sector, and likely in the name of rescuing that very collaboration.

Marxists are fond of wondering at capitalism's ability to save itself from crisis each time. We have all read endless discussions of capitalism's remarkable flexibility, corrective ability, and strength at appropriating, co-opting, and commodifying rebellious tendencies like "1960s counter-culture." This is the wrong way to look at it. Capitalism has never co-opted a serious challenge to its logic of accumulation and has never saved itself from anything. It is the working class that has saved capitalism each time, through hard work, lower pay, great sacrifices, and a terrible price paid in "devalorization of capital" - a fancy term that 
incorporates the destruction of fixed capital: rusting machinery, decaying housing stock, or factories obliterated by aerial bombing, as well as the destruction of variable capital: loss of work skills through inactivity, the destruction of self through unemployment, and, of course, mass death from war.

If this is like every other economic crisis, big or small, it will be resolved by our social class through large numbers of people working harder with less reward and the rest becoming surplus population to be "devalorized." The last major depression was finally resolved through "the ultimate sacrifice" by millions of Japanese, German, American, Indian, British, African and other national working classes in a great war for their boss' great profits. This is how capitalism "saves itself", through our sacrifice, not made possible by any great flexibility or capitalist genius, but rather by capitalism's extreme inflexibility in regard to its own logic of accumulation, and of course, the historical weakness of the working class in its inability to act as a "class for itself" and promote a viable alternative logic to the Schumpeterian cycles of the market.

A crisis always presents new people with new voices promoting new possibilities for doing things differently and there will always be people standing just a step to the right of those new possibilities telling us that "we have nothing to fear but fear itself," or as Obama put it, "the road ahead will be long," and we need "a new spirit of sacrifice," a "new spirit of patriotism... where each of us resolves to pitch in and work harder." In such a period when there is the possibility for doing new things, hope is useful, enthusiasm and the spirit of "yes, we can" is great, but theory and analysis is more useful. We are still waiting to see convincing explanations for how a crisis of this magnitude could be created by one national mortgage market, even a giant one like that of the US; why regulation will solve problems it didn't solve in the recessions of the late 1950s, mid 1970s, early 1980s, early 1990s, or first years of the new century, much less the Great Panic of 1837 or the "great depressions" of the 1870s-90s and the 1930s; and more to the point, why anybody should have to sacrifice at a time when the global economy has gone through almost 20 years of unprecedented advances in productivity and we are all working longer and harder hours than in the past. As Marx suggested in his notion of the tendency of the rate of profit to fall, it is exactly at the point where capitalism has greatly increased its productivity that we may expect crisis. Is this crisis driven by a falling rate of profit? We are not sure, but what we are sure of is that there are better economic logics than capitalism, even a regulated, social-capitalism, upon which to base our social existence.

As anthropologists struggling within and against the unconscious logic of capitalism and the conscious agonistic policies of its governance institutions, we recognize that our biggest potential contribution to action, both antagonistic and transformative, is solidarity. For this reason this latest issue of the new Dialectical Anthropology focuses on solidarity. We begin with a major forum, organized by Leslie Gill and Sharryn Kasmir, on this crucial personal, professional and political question. In this forum they bring together a group of engaged, partisan anthropologists to discuss what they do; and why, how and what it means to them and the people they work with to choose an active and politically conscious role in the field. Whether the anthropologist is engaging local, national or internationally 
recognized political struggles with battle lines already drawn before she arrives, or the hurtful inclusions and exclusions of "peace" under capitalism presented as fait accompli (as Winnie Lem observes), the notion that fieldwork can be anything but observant-participation is a bourgeois professional fantasy. But then the question becomes: how to address the contradictions built into our strange way of making a living amid not simply contradiction, but often plain and obvious struggle.

Continuing with the problem of solidarity, George Baca presents a major article on one of the oldest, most enduring, and propinquitous questions facing American anthropologists (or at least those who recognize that what we do is inherently political): race, the black question, and the outcome of the civil rights movement. Made all the more important by the recent election of the first non-white president, Baca seeks to up the ante on left critiques of the multiple institutional class compromises that emerged from the 1950s/60s US Civil Rights Movement struggle. Diane Austin Broos and Charles Price join him in this important discussion.

Finally, we present a report from the field by Martha Lincoln on the peculiar relationship in Vietnam between urban pushcart cuisine, new national institutions of governance, and the demands of global financial institutions; a review by David Brotherton of Steven Gregory's new book, The Devil Behind the Mirror: Globalization and Politics in the Dominican Republic; and a discussion of the life of John Cammet, a recently deceased colleague, whose death touches our editorial board in a number of important personal and professional ways and whose work continues to make great contributions to the politics of solidarity and transformative action. 